NBER WORKING PAPER SERIES

\title{
MODELING AND MEASURING RUSSIAN CORPORATE GOVERNANCE: THE CASE OF RUSSIAN PREFERRED COMMON SHARES
}

William N. Goetzmann

Matthew Spiegel

Andrey Ukhov

Working Paper 9469

http://www.nber.org/papers/w9469

\author{
NATIONAL BUREAU OF ECONOMIC RESEARCH \\ 1050 Massachusetts Avenue \\ Cambridge, MA 02138 \\ January 2003
}

We thank Arturo Bris for his help and suggestions. The views expressed herein are those of the authors and not necessarily those of the National Bureau of Economic Research.

(C)2003 by William N. Goetzmann, Matthew Spiegel, and Andrey Ukhov. All rights reserved. Short sections of text not to exceed two paragraphs, may be quoted without explicit permission provided that full credit including notice, is given to the source. 
Modeling and Measuring Russian Corporate Governance:

The Case of Russian Preferred and Common Shares

William N. Goetzmann, Matthew Spiegel and Andrey Ukhov

NBER Working Paper No. 9469

January 2003

JEL No. F3, G3

\section{$\underline{\text { ABSTRACT }}$}

This paper examines governance explanations for the discount of preferred shares to common shares in the Russian market. Conflicts between shareholder classes may help explain the discount. However, for this to be the sole explanation the estimated models suggest that the magnitude of future adverse shareholder events would have to be very high. Nevertheless, evidence of a common factor potentially related to governance seems evident in the data, implying that corporate control issues may at least be partially responsible for the observed preferred share discount.

William N. Goetzmann

International Center for Finance

Yale School of Management

135 Prospect Street

New Haven, CT 06520

and NBER

william.goetzmann@yale.edu

Andrey Ukhov

Yale School of Management

135 Prospect Street

New Haven, CT 06520

andrey.ukhov@yale.edu
Matthew Spiegel

Yale School of Management

135 Prospect Street

New Haven, CT 06520

matthew.spiegel@yale.edu 
...Russia has a strategic goal - to become a country that makes competitive goods and renders competitive services. All our efforts are committed to this goal. We understand that we have to solve questions pertaining to the protection of owners' rights and the improvement of corporate governance and financial transparency in business in order to be integrated into world capital markets.

Vladimir Putin's speech at the World Economic Forum in Moscow $(10 / 30 / 01)$

It is widely believed by participants in the Russian market that corporate governance issues are at least as important as fundamental economic factors in the valuation of Russian securities. In fact, this is what makes the Russian markets so appealing for academic research. Governance in Russia presumably has a first-order, rather than a second-order valuation effect, an observation that may explain why many Russian companies look attractive based on various valuation metrics. For example, oil firms currently appear to be undervalued on the basis of the ratio of reserves to their stock price. These attractive valuations, however, are meaningless to minority shareholders if managers or a controlling shareholder block can transfer resources to themselves. Hence corporate governance issues have attracted considerable investor attention. One of the leading Russian investment banks, Troika Dialog, publishes a weekly newsletter Corporate Governance Weekly. The publication discusses changes in laws and regulations, reports legal cases, and discusses corporate events. Undoubtedly, their customers consider this information value-relevant.

The emerging awareness of corporate governance issues in the last two years has, perhaps, lead to some positive changes in the Russian corporate governance landscape. For example, there are now a few cases in which minority shareholders have successfully defended their rights. Nevertheless, a natural presumption about the primary determinants of share price in Russia is that 
issues of control far outweigh such measures of earnings and asset values - hence the quote from President Putin above.

This paper explores an odd empirical deviation from the law of one price that might appear - at first - to be due to the relatively poor legal protections for minority shareholders in Russia. In order to understand this deviation, the analysis examines models of minority expropriation designed to parameterize this intuition. It finds that assumptions regarding the magnitude and timing of expropriation would have to be so extreme as to be incredible - even in the context of Russia's rough and ready corporate environment. For those who insist on a pure corporate control explanation, this leaves the conclusion that extreme investor priors about expropriation have very large effects on the valuation of Russian securities.

The empirical analysis focuses on the relative pricing of the common and preferred shares of Russian companies. These securities differ only in their relative proportions in the equity capital structure, and in the type of issues on which they vote. In addition, preferred shares have a novel constraint on dividends that makes it easy to model their relative value to common. Unlike typical U.S. preferred stocks, which have a promised annual cash payment, the dividends of Russian preferred shares are legally bounded below by the dividends to the common. If, as normally assumed in equity valuation, the stream of future dividends represents all the benefits that can accrue to shareholders, then the common and preferred valuation ratio should be reversed - the preferred should always sell for more than the common. In fact, they almost never do. In this paper, we investigate whether this discrepancy may be the result of the potential for expropriation of one class of shareholders by another. 
It is well known that differential voting rights can account for large pricing differentials in some markets (c.f. Zingales, 1994\&1995). However, a useful question is whether the pricing differential between voting and non-voting shares correctly estimates the ex ante value that can accrue to one class of shareholders. This paper builds a simple model of expropriation and then evaluates it using current Russian company share prices and dividends. Empirically it appears that the magnitude of future adverse shareholder events will have to be very high to justify the preferred share discounts that currently prevail. A factor analysis is then conducted in order to assess whether the risk of such expropriation events is idiosyncratic or systematic. The results indicate that there exists a common factor potentially related to investor perceptions about corporate governance. Thus, at least some of the relative discount may be due to corporate control issues. ${ }^{1}$

\section{Russian Preferred Shares}

When the Russian government privatized its industries, for many firms, it created two classes of stock. The first, common shares, are typical of those found in many western countries. The second, however, is relatively unique. At the time, the government wanted to protect each firm's employees, while simultaneously giving them a stake in their own firm. To do so, "preferred" shares were created and distributed. These shares are very different from those normally seen in the U.S. and European markets in that they come with special voting and cash flow rights. The apparent purpose of these rights is to ensure that the preferred shares remain at least as valuable as the common. However, despite these protections the common nearly always sells for more than the preferred.

\footnotetext{
${ }^{1}$ While corporate control issues may not fully explain the discount this paper does not claim the unexplained part must be due to irrationality in the market. Indeed while that may be true, it may instead be that the price discrepancy arises from the potential for multiple market equilibria such as those found in Spiegel (1998).
} 
Typically the answer to a "puzzle" like this is that the price of the common includes control, and liquidity premia. Of course, such models can produce relative market prices like those observed in the Russian data. But, as the analysis presented here shows, such explanations are difficult to reconcile with the size of the price discrepancy. Empirically, the difference in liquidity between the two securities is not that large. This leaves only the hypothesis that some fairly dire scenarios await the preferred shareholders with a high degree of probability in the very near future. Thus, this paper presents something of puzzle in the sense of the famous "equity premium puzzle." Yes, corporate control models can explain the observed phenomena, but the estimated parameters from such models do not seem reasonable.

Russian companies are allowed to issue bonds, common stock, preferred stock, warrants and convertible bonds. For the purposes of this paper the preferred shares have two special rights of particular salience. First, most company charters require that preferred shares receive a dividend at least equal to some fixed percentage of the annual net profits, often $10 \% .^{2}$ (Note, they differ from western preferred shares that typically offer a fixed annual monetary amount.) Second, the preferred shareholders must receive a dividend at least as large as the dividend given to the common shares. A typical corporate charter such as that for Surgutneftegaz spells this out as follows:

The total amount of the dividend on each preferred share shall be fixed at 10 percent of the net income of the Company at the end of the last financial year divided by the number of stock which constitutes $25 \%$ of the company's share capital. If the amount of dividends paid

\footnotetext{
${ }^{2}$ This, of course, means that the definition of net profits can be crucial to valuation. In recognition of the potential for concealing profits to the detriment of preferred shareholders, Russian regulators in the year 2001 "tightened" the definition of accounting profits. In fact, however, most Russian companies have been paying out, rather than avoiding, significant preferred dividends. (See Table 1, which lists the dividends paid on common and preferred shares for nine firms.)
} 
by the Company on each common stock in a certain year exceeds the amount of dividends payable on each preferred stock, the amount of dividends payable on the latter must be increased to the amount of dividends payable on the common stock. The Company shall have no right to pay any dividends on the preferred stock otherwise than in the manner provided for by its Articles of Incorporation. ${ }^{3}$

Thus, relative to the common shares, the preferred shareholders have apparently been promised the larger cash flow stream. As a result, for corporate control issues to explain the observed prices one needs to assume that at some point an entity will figure out a way to circumvent the charter's language and transfer cash flow from the preferred to the common.

The above discussion naturally leads to the question of just how much protection has been afforded the preferred shareholders. Cash flow promises are worthless unless backed up with sufficient control rights. Recognizing this, Russian company charters protect the preferred shares' dividends against splits and reverse splits. In other words, companies are not allowed to simply increase dividends to the common shareholders by a factor of ten by splitting each share of common ten for one. Other protections vary across firms. Some Russian companies simply pool all of the equity votes when determining if a particular measure has or has not passed. ${ }^{4}$ Other firms offer the

\footnotetext{
${ }^{3}$ Resolution on Issue of Securities Preferred Registered Stock of Open Joint Stock Company Surgutneftegaz, September 20, 1997.

${ }^{4}$ By law the preferred can only represent up to $25 \%$ of a firm's capital as calculated via the original par value of the preferred and common equity. This implies that even if the preferred shareholders unanimously oppose a measure it will pass if the common votes at least 2 to 1 in favor. On the other hand, anybody that owned $100 \%$ of the preferred stock and $1 / 3$ of the common would have voting control. Thus, even in this case, it is not clear that control issues should either negatively or positively influence the value of the preferred shares relative to the common.
} 
preferred shareholders even more explicit protection. For example, the Surgutneftegaz charter states that in the event of proposed

... modifications or amendments to the Charter may affect the rights and interests of the first issue Preferred Stock owners ... the decision has to be ratified by those owning two thirds of the Preferred Stock ...

With this clause in place, and sufficient legal protection via the courts, it would appear that the preferred shareholders should be protected against any value transfers to third parties.

Given the legal protections afforded to the preferred shareholders, why do they sell for less than the common? One obvious answer is that via clever legal maneuvering somebody will find a way around even the strongest protections, thus draining value from the preferred to the common shareholders. Several international studies on voting rights confirm that control is valuable. According to Levy (1983), Rydqvist (1996), Horner (1988), and Zingales (1994) premiums are paid for voting control in Israel, Sweden, Switzerland, and Italy. Hanouna, Sarin, and Shapiro (2001) estimate the value of control for a sample of transactions in G7 countries. They report control premiums in the United States of approximately $30 \%$.

It is important, however, to study specific mechanisms by which voting control translates into altered shareholder group cash flows since this ultimately determines valuation. Thus, this paper goes beyond a simple statement that voting rights account for the valuation discrepancy. Instead, it develops two simple models of expropriation and then evaluates them with current share price and dividend data. The estimated parameters indicate that if future adverse shareholder events are to explain the data, they will have to be very strong and happen very quickly. The paper concludes with a factor analysis to assess whether the risk of such expropriation events is idiosyncratic or systematic. Here the findings indicate that there may very well be a common factor potentially 
related to governance. So, while governance issues undoubtably explain some portion of the observed relative valuations, other explanations would also seem to be needed.

The paper's structured as follows: Section 2 describes the history and basic characteristics of the Russian stock market. Section 3.1 looks at the relative liquidity of the preferred and common shares. Section 3.2 examines several corporate control explanations for the observed common to preferred price ratios. Section 3.2.1 estimates a wealth transfer model, and Section 3.2.2 a takeover premium model. Section 4 looks at the related literature on the corporate control premium in other countries. Section 5 tests for a common corporate governance factor that may be influencing the common to preferred price ratio. Finally, Section 6 concludes.

\section{The Russian Stock Market}

\section{$2.1 \quad$ History}

Over the past five years, the privatization of the Russian economy has virtually undone the most famous nationalization of industry in history. In 1917, when most Russian corporations were acquired or seized by the revolutionary government, the domestic and international market in Russian debt and equity instruments was one of the most active in the world. It operated under a set of securities laws that had developed over the course of a century, beginning with the founding regulations of the Saint-Petersburg stock exchange in 1816. In the decades before the Russian Revolution, the control of much of the nation's natural resources and industrial assets were held by foreign and domestic investors, including oil fields, mines, railroads, tramways, electric utilities and banks, to name only a few. In the late $19^{\text {th }}$ and early $20^{\text {th }}$ century, in a manner surprisingly similar to America's own Gilded Age, Russia's eastward expansion and rapid development was financed 
by vigorous capital markets. All this changed with the expropriation of Russian assets by the State and the repudiation of much of the Tsarist debt by the new Russian Government.

With settlements of the Russian government debt in the early 1990's, Russia has returned to the global capital markets. By the same token, with the vigorous privatization of Russian state-run enterprises beginning in 1993, the State Property Committee (GKI) has overseen the transition of huge sectors of the Russian economy back to their pre-revolutionary status. The first steps taken in 1993 distributed the ownership of a large fraction of Russian enterprises directly to Russian citizens, and instantly established the need for a liquid securities market. Privatization continued until the Russian economic crisis in 1998, under a variety of auction, secured loan, and direct transfer programs that resulted in the creation of large-scale publicly traded companies, that, like their prerevolutionary predecessors, have attracted the interest of foreign investors.

Russian securities regulators have been challenged to keep up with the pace of privatization. Security investors require enforceable property rights, laws against fraud, clear corporate rules, organizational transparency - in short, the entire framework of institutional rights and laws that have developed in the United States and other capitalist nations over the period since 1917. Despite starting virtually from scratch, Russian securities regulators have done a remarkable job in dealing with the pace of change, with the Federal Commission for the Securities Market taking the lead in seeking to create a positive environment for investment. However, the Russian market is so new that many issues have yet to be tested, despite the increasing sophistication of market participants and the increasing complexity of corporate restructurings.

\subsection{Current Market}


The majority of stock trading in Russia occurs on the floor of The Moscow Interbank Currency Exchange (MICEX) or through the Russian Trading System (RTS). ${ }^{5}$ MICEX began trading stocks in March 1997, and by the end of the year it listed 50 stocks from 33 different companies. In 1999 MICEX became the volume leader among Russian exchanges for equity trading. Equity trading on MICEX accounted for $53 \%$ of all equity trading in Russia in 1999. By the end of 1999 MICEX listed 174 stocks by 112 issuers. In the year 2000, the volume of equity transactions on MICEX reached 472 billion Rubles a six-fold increase against 1999. Such Russian blue chips as Lukoil, Mosenergo, Rostelecom and Norilsk Nickel trade on MICEX.

The RTS Stock Exchange is an electronic trading floor established in 1997 by leading Russian brokers and dealers to consolidate regional securities markets. RTS traces its origins back to the Russian Trading System - the first electronic trading system in Russia. It began operations in September 1995. Presently, RTS lists and trades all Russian blue chips and many regional firms.

Figure 1 plots the RTS Index and RTS daily trading volume over the period September 1, 1995 to August 31, 2001. The RTS Index is a value-weighted index computed by the Russian Trading System based on U.S. dollar prices of 63 stocks. The performance of the index was striking until the end of the summer of 1997. Russia appeared at the time to be a vibrant emerging market exhibiting high share price growth. Average daily trading volume grew from \$2,276,733 in 1995 to $\$ 11.8$ million in 1996 and reached $\$ 36.6$ million during the first half of 1997 . The all time high of \$216 million in trading on one day also occurred on October 3, 1997 - over 100 times the average daily volume two years previously.

\footnotetext{
${ }^{5}$ Negligible amount of trading in stocks takes place on regional exchanges, - in Samara, Rostov, St. Petersburg, Nizhny Novgorod, and Ekateringburg.
} 


\subsection{The Crash of 1997}

At the end of October 1997, the Russian stock market tumbled. The RTS Index lost 93\% of its value, falling from 571.66 on October 6, 1997 to an all-time low of 38.53 on October 5, 1998. The crisis of 1998 not only destroyed the value of the Russian stock market, but also brought trading to a near halt. On August 13, 1998, the Russian market closed after the first hour of trading as the average market price dropped $6.5 \%$. The average daily trading volume on RTS for the last six months of 1998 was $\$ 8.9$ million. There were many days in September and October when trading volume was below $\$ 1$ million. The least active day in the history of RTS was September 25, 1998 with the total volume of trading of only $\$ 163,350$ ! In short, Russia's new public capital market nearly ceased to exist.

The trigger for the 1997 crash was almost certainly the Asian currency crisis that began in the late Summer and early Fall of that year. Slumping energy prices during the period also hurt Russia's largest firms. The Russian government's debt crisis added to the problem, ultimately resulting in a $\$ 40$ billion default on August 17, 1998. The Russian stock market eventually responded to the economic recovery of 1999 . The RTS index gained nearly $200 \%$ in 1999 , and dropped only $20 \%$ in 2000 . The index gained $57 \%$ over the first eight months of 2001 . Trading volume, however, has not recovered to the pre-crisis levels. The average RTS daily trading volume was $\$ 22.2$ million in 2000 , and $\$ 18$ million in 2001, substantially lower than in 1997 . Despite survival, the Russian stock market remains very small compared to the size of the economy. The market capitalization of the RTS Index stocks equaled \$52.92 billion as of October 25, 2001. According to The World Factbook 2001 published by the CIA, Russia's Gross Domestic Product for 
the year 2000 is estimated at $\$ 1.12$ trillion. By comparison the same source estimates U.S. GDP to be $\$ 9.963$ trillion.

\subsection{The Historical Price Performance of Russian Preferred Shares}

As noted earlier, Russian law states that the preferred shares must receive a cash flow at least as large as the common. Thus, it appears that the price ratio of the common to the preferred should never exceed unity. One can test this relationship by looking at the following five Russian companies: Unified Energy System (EESR), Lukoil Holdings (LKOH), Norilsk Nickel (NKEL), Rostelecom (RTKM), and Surgutneftegas (SNGS). These firms have been selected since they have actively traded preferred and common shares on both the Russian and U.S. stock exchanges (the latter via ADRs). As of October 25, 2001, common and preferred shares of these firms accounted for over $53 \%$ of the market capitalization of the RTS Index.

Figure 2 shows the equally weighted index of the common to preferred share price ratio for the five firms. For each day $t$, for each of the five firms $i, i=1, \ldots, 5$ compute the ratio $X_{i, t}$ of the

price of a common share, $P_{i, t}^{c}$, to the price of a preferred share, $P_{i, t}^{p}: X_{i, t}=P_{i, t}^{c} / P_{i, t}^{p}$. Then compute the equally weighted index (EWCP Index) based on the values of $X_{i, t}$ for the five firms. Figure 2 also shows the stock index computed by the Russian Trading System (RTS Index). The EWCP Index values stay above one (the minimum achieved value is 1.28 ), representing relatively high valuation of the common versus the preferred. The figure also displays a very high volatility pattern for the twelve months beginning in the summer of 1998. Beginning from the summer of 1999, the Russian stock market began its recovery from the 1998 crisis, as represented by the growth in the RTS Index. The EWCP Index began its descent to its pre-crisis level only at the beginning of 2000. The average common to preferred ratio did not reach its pre-crisis level until 2000. 
The individual price series are shown in Figure 3. Only for Norilsk Nickel are the prices close to being equal throughout the sample period. However, in December 2000, the prices of Lukoil common and preferred also began to converge. Although Figure 3 only focuses on five companies the relative valuation of preferred and common shares is an important issue since many additional Russian companies have these two share classes. Table 2 presents descriptive statistics indicating the importance of the preferred share market in Russia. The data was retrieved manually from the archive maintained by the RTS. The RTS Stocks Archive includes all stocks that were, at some time since September 1, 1995, listed on RTS. There are 909 stocks in the archive. Of these 651 (72\%) are Common, and 258 (28\%) Preferred. There are 251 companies that have common and preferred pairs. For some of these companies, however, there are no trades for either the common or the preferred in the database. The remaining 154 companies have, at some date at least, had both common and preferred listed on RTS and recorded some trades for both classes of shares. Another measure of the importance of preferred shares is their relative trading volume. During the period from September 1, 1995 until August 31, 2001 trading in common and preferred shares issued by the firms with both classes of stock accounted for $73 \%$ of all RTS trading. Preferreds are a small portion of the index by capitalization, however. There are 63 securities in the RTS Index. As of October 25, 18 of the securities were preferred stocks, accounting for $5.55 \%$ of the index market capitalization. The companies that have both classes of shares account for $65.21 \%$ of the index market capitalization. 


\section{Explaining the Common/Preferred Price Ratio}

\subsection{Liquidity}

Liquidity differences across securities may offer the simplest potential explanation for the observed preferred to common price ratio. If the preferred are less liquid they will presumably sell for less, even if they have higher expected future cash flows. Table 3 presents some evidence on this issue. Panel A shows that the volume of trade in the preferred shares for each firm is significantly lower than the volume of trade in the corresponding common. In terms of total dollars traded, the common shares experience two to ten times as much volume. However, these figures converge to a large degree when divided by the market value of each class. ${ }^{6}$ Thus, trading volumes in each security class appear to be roughly proportional to their market value - an expected result if the relative liquidity levels are similar.

Another way to look at the liquidity issue is via a comparison with U.S. securities. Table 3 Panel B reports the results from a matching sample of U.S. firms. This sample contains the ten stocks closest in market value (five above and five below) to each Russian security in our sample. That is, each Russian firm has ten matching U.S. firms for its common and another ten for its preferred. Not too surprisingly, the U.S. firms are a lot more liquid than their Russian counterparts. For many of the comparison groups the U.S. market has almost 100 times the trading volume.

While the U.S. market is clearly more liquid overall, if one looks across pairs another pattern emerges. For any one firm, the U.S. matching sample for the common tends to have considerably

\footnotetext{
${ }^{6}$ One caveat - the entire analysis ignores the U.S. volume in ADRs and volume in other nondomestic securities markets, which may substantially influence a particular trader's ability to get into or out of a position.
} 
more liquidity (relative to market value) than the set used to match the preferred. For example, the Rostelecom ratios for the common and preferred trading volumes (relative to market value) are 0.352 and 0.263 respectively. For the matching U.S. sample they are 3.001 and 1.361 . Thus, many of the Russian preferred issues appear to be have more trading volume relative to their common counterparts than one would expect from an examination of U.S. companies with equivalent market values.

Although it is commonly accepted that liquidity is relevant to valuation, no researcher has ever suggested that the liquidity premium for small stocks in the U.S. is anywhere near the levels needed to reconcile the prices of the Russian preferred and common shares. Consider then Table 3 as a comparison of the trading volume in small U.S. companies (those matched with the Russian preferred shares) and large U.S. companies (those matched with the common). The table suggests that liquidity drops off with size somewhat faster in the U.S. than in Russia. Thus, it seems reasonable to conjecture that the liquidity premium for small U.S. companies puts an upper bound on how large a liquidity premium can exist in the Russian market for preferred shares. Overall, it seems unlikely that liquidity can explain more than a small fraction of the observed Russian preferred share discount.

\subsection{Corporate Control}

For corporate control issues to explain the price discrepancies between the Russian common and preferred shares then at some point in time the common shares must expect to receive a larger cash flow than the preferred. This differs from the simple statement that corporate control issues have a large impact on security prices. For example, imagine that management can expropriate a 
large fraction of a firm's cash flows. ${ }^{7}$ That in and of itself should not cause the preferred shares to sell for less than the common. For better or worse, the siphoned off cash flows do not aid the marginal holder of the common; an ordinary investor that cannot expect to share management's private benefits. Thus, while corporate control may strongly impact the absolute values across security classes, it can only effect relative prices by somehow diverting future cash flows from one class to the other. For the common to sell for more, its marginal holder must expect to reap cash flow benefits or in a competitive equilibrium the price will not be bid up past that of the preferred.

\subsubsection{A Model of Direct Wealth Transfers from the Preferred to the Common}

Based upon the above discussion consider the following simple perpetual growth model, modified to allow for the possibility that at some date in the future cash flows may be diverted from the preferred shares to the common. Define $D_{c}$ as the total dividend paid out to the common shareholders and $D_{p}$ the dividend paid out to the preferred shareholders. Let the payout ratios for each class of shares equal $\gamma_{\mathrm{c}}=D_{c} / E$ for the common and $\gamma_{\mathrm{p}}=D_{p} / E$ for the preferred, where $E$ equals the firm's next period earnings. Since the model assumes that the firm grows at a constant rate $(g)$,

${ }^{7}$ Even this is becoming more difficult as there are emerging ever more binding restrictions on what can be done to make this happen. For example, in 1999 Viksunsk Pipe tried one of the widely used tricks for diluting minority shareholders. In this ploy, the Board at the Annual General Shareholders' Meeting (AGM) or Extraordinary General Shareholders' Meeting (EGM) of the company authorized a secondary issue of common shares, to be placed with insiders via closed subscription, which dilutes the common. Shareholders opposed to the issue were offered a redemption price that was substantially lower than the price, at which the new issue is placed, $P_{p l}$. Minority shareholders could not participate in the subscription, but they also did want to sell their shares at an artificially low price. Viksunsk Pipe offered prices set at $P_{p l}=\$ 10.7$ and $P_{r e d}=\$ 3$, where $P_{\text {red }}$ is the redemption price. Dissenting minority shareholders consolidated $9.4 \%$ of the charter capital and demanded that the company redeem their shares at a fair price. The shareholders ultimately won the battle, and reached an agreement to put their shares to the company at $\$ 10$ per share. While this is only one example, it illustrates the kind of corporate conflicts and legal changes that are happening in Russia right now. 
it is natural to assume that it arises from a constant "plowback" rate of the firm's earnings $(E)$ into new capital, $E\left(1-\gamma_{c}-\gamma_{p}\right)$. Let $R O E$ represent the firm's return on equity, then $g=\operatorname{ROE} \times\left(1-\gamma_{c}-\gamma_{p}\right)$.

Absent issues of expropriation, the ratio of the price of the preferred to the common will simply equal the ratio of their current dividends. However, under the hypothesis that control issues explain the relative pricing of the common and preferred shares the model needs to allow for future transfers of cash flows. To do so assume that at some date $T$ the preferred shareholders will have their shares swapped for shares of the common. Let $\alpha$ represent one minus a swap ratio of common shares for preferred shares. ${ }^{8}$ A value of zero implies that the common is swapped one for one in proportion to the dividends being paid to each class, and a value of one implies full expropriation of the preferred shareholders.

Under the above scenario the preferred shareholders earn $\gamma_{\mathrm{p}} E(1+g)^{t-1}$ in period $t<T$. From date $T$ onward they earn $(1-\alpha) \gamma_{\mathrm{p}} E(1+g)^{t-1}$, the rest going to the common shareholders. Some simple manipulations of the annuity and perpetuity formulae (assuming a constant discount rate $r$ ) yields a valuation equation for the preferred shares of

$$
P_{p}=\frac{\gamma_{p} E}{r-g}\left[1-\alpha\left(\frac{1+g}{1+r}\right)^{T}\right]
$$

Similarly, the common shareholders earn $\gamma_{c} E(1+g)^{t-1}$ in period $t<T$, and then $\left(\gamma_{\mathrm{c}}+\alpha \gamma_{\mathrm{p}}\right) E(1+g)^{t-1}$ so their shares are worth,

${ }^{8}$ In fact, some preferred shares are convertible into common at the will of the company. A notable example is the conversion of Norilsk Nickel which redeemed one class of convertible preferreds 1 for 1 with common shares. 


$$
P_{c}=\frac{E}{r-g}\left[\gamma_{c}+\alpha \gamma_{p}\left(\frac{1+g}{1+r}\right)^{T}\right] .
$$

Thus, the price ratio of the common to the preferred equals

$$
\frac{P_{c}}{P_{p}}=\frac{\left(\gamma_{p}+\gamma_{c}\right)(1+r)^{T}}{\gamma_{p}\left[(1+r)^{T}-\alpha(1+g)^{T}\right]}-1 .
$$

Since the model contains four free parameters, one can now see how the values of $g$ and $T$ vary with each value of $r$ and $\alpha$. Before going to the numerical analysis note that the growth rate only enters the equation in terms of the form $[(1+g) /(1+r)]^{\mathrm{T}}$. Thus, varying $\alpha$ will not influence the solution to $g$, only the solution to $T$.

Using equation (3) take Surgutneftegaz as an example. In 1999, investors received \$0.74 per 1,000 shares of common and $\$ 3.19$ per 1,000 shares of preferred. ${ }^{9}$ Assuming no expropriation (either $\alpha=0$, or $T=\infty$ ) the ratio of the value of the preferred to the common shares should be $3.19 / 0.74$ or 4.3. Instead, the preferred typically selling for less than half the common. On March 22, 2001 (a typical day) the preferred sold for $\$ 0.1115$ and the common $\$ 0.23125$, or a ratio of 0.48 .

Table 4 displays the fitted value for $g$ and $T$ given various values of $r$ and $\alpha$ for six firms with enough contemporaneous price and dividend data to be able to meaningfully calculate model values. The table shows that, if the expropriation rate equals $60 \%$ or less then at the current market prices,

${ }^{9}$ At the end of 1999 Surgutneftegaz had 23,725,994,705 common shares outstanding. It then registered an additional 12 billion shares on June 26, 2000 and paid 1999 dividends on these as well. On the preferred side the firm had 7,701,998,235 preferred shares outstanding. This implies a total payment to the common shareholders of $\$ 26,437,236$ and to the preferred of $\$ 24,569,374$. 
it pays to short the common stock and use the proceeds to purchase the preferred shares at most reasonable interest rates. Even with an expropriation rate of $65 \%$ for four out of seven of the sample firms the event that would cause this wealth transfer needs to occur within three years to justify the current relative market prices. One item the table underscores is the close tie between the expropriation level and date. For the most part, changes in the interest rate impact the firm's estimated growth rate and not the expropriation date. Conversely, changes in the expropriation rate have a dramatic impact on the expropriation date.

The most striking result of the analysis is that, given most reasonable expropriation rates (60\% or less), the time to expropriation would have to be very soon to justify the current price differential between Russian common and preferred shares. In particular, for Surgutneftegaz, the only way to justify the observed market prices - even with our "disaster scenario" models - is to assume that the market anticipates a fairly substantial wealth transfer from preferred to common in the next few years. Sophisticated investors in Russian shares are more equipped than we to judge the reasonableness of these assumptions, but even in the fluid regulatory framework of the modern Russian securities markets, such expropriation assumptions would seem to be dire.

\subsubsection{Expropriation via Takeovers}

Recent mergers, such as the 1999 acquisition of the oil company Komitek by Russia's largest oil firm Lukoil, have involved swaps of the acquiring firm's preferred shares for the acquired firm's common (and presumably their preferred) shares. If the bidding firm can purchase the target's common shares for more than the preferred then this may explain the observed relative prices, an event not unheard of in Russia. For example, in July of 1999 YUKOS released the ratios at which it proposed to swap its shares for those of its three subsidiaries: Yuganskneftegaz (YFGA), 
Samaraneftegaz (SMNG), and Tomskneft (TOMG). Common shareholders in the subsidiaries could swap their shares for those of the parent company YUKOS at the following ratios: 7 YUKO for 1 YFGA, 4 YUKO for 1 SMNG, and 3 YUKO for 1 TOMG. Preferred shares in each subsidiary could be tendered for half as many YUKO commons. According to Troika Dialog, YUKOS valued its shares at 6 rubles $(\$ 0.25)$ per share. This implied that YFGA was valued at $\$ 1.75$, SMNG at $\$ 1.00$, and TOMG at $\$ 0.75$. Troika Dialog also reported that "an independent appraisal commissioned by shareholders produced the following fair value estimates per share: YFGA - \$11.25, SMNG - \$1, TOMG - \$8.5." ${ }^{10}$ Whether or not common shareholders of the three subsidiaries were given an attractive offer may be debatable. Still, preferred shareholders were offered only half as much.

To test the hypothesis that differential takeover terms for the common and preferred shareholders explains the observed differential start with the perpetual growth model developed in Section 3.2.1. Now, drop the assumption that at date $T$ a direct wealth transfer takes place, and replace it with the assumption that a takeover occurs instead. Further assume that the common shareholders can capture all of the acquisition premium from the takeover. Now, the only difference between the two share prices is the expected discounted future value of the per-share acquisition premium. Thus, the preferred's value equals:

$$
P_{p}=\frac{\gamma_{p} E}{r-g}
$$

and the common's:

${ }^{10}$ Bulletin \# 43 On Corporate Governance Actions. Troika Dialog. 15 July 1999 


$$
P_{c}=\frac{\gamma_{c} E}{r-g}+m \frac{\gamma_{c} E(1+g)^{T}}{(r-g)(1+r)^{T}}
$$

where $m$ equals the takeover premium, and $T$ the takeover date. The price ratio can thus be expressed as

$$
\frac{P_{c}}{P_{p}}=\frac{\gamma_{c}\left[(1+r)^{T}+m(1+g)^{T}\right]}{\gamma_{p}(1+r)^{T}} .
$$

There are again four free unobservable parameters $\mathrm{g}, r, m$, and $T$.

Table 5 displays the fitted values of $T$ and $g$ for various values of $m$ and $r$. Under reasonable assumptions it seems possible to use a takeover premium model to explain some small part of the structural relationship between preferred and common shares, but not most of it. The results generally indicate that even if a takeover were to occur in the very near future the preferred shares offer the better investment value. Consider the case where the merger premium equals nine times the value of the common stock's future cash flows. ${ }^{11}$ For discount rates between 5\% and $15 \%$ four out of the eight observed price ratios cannot be explained via the model, even if a takeover were to occur today. For one of the remaining firms, investors need to believe that such a takeover will occur in the next six years. Thus, even a significant takeover premium can only explain the data in three out of the eight cases.

Table 5 also includes the implied price-earnings ratio at which the takeover would occur

\footnotetext{
${ }^{11}$ Note that the fitted values are set to rationalize today's price. Thus, it is not the case that the results are due to a systematic undervaluation of the common stock's future cash flows absent a takeover. Rather the model produces numbers such that both the takeover payout and the future cash flows discount to the current market price.
} 
under the model's assumptions. ${ }^{12}$ In many cases they seem too low, and when they are not then $T$ seems large enough to explain the pricing discrepancies as takeover premiums. However, this hides a number of faults. First, earnings in Russia have been growing at an anemic rate. Thus, given the historical data, the purchaser is buying a cash flow that seems as likely to go down as up. Second, earnings growth has been weak despite relatively low payout ratios. It is this combination that makes it difficult for the model to explain the data under reasonable assumptions. The current holders of the equity appear to be paying a very high price, for what seem to be limited immediate cash flows, and future cash flows will need to depart from the historical pattern of low growth.

Still, it is somewhat disturbing that the model produces such low predicted price-earnings ratios upon the implementation of a takeover. To rectify this, Table 6 calculates $g$ and $T$ under the assumption that each firm will set $\gamma_{c}$ equal to $\gamma_{p}$, the maximum allowed by law, starting immediately and continuing into the future. This departure from historical precedent allows the model to produce seemingly more price-earning takeover ratios. However, for four of the firms even with projected price-earnings ratios well over twenty-five one cannot justify the current relative price of the preferred and common shares.

\section{$4 \quad$ Preferred Share Voting Rights - The Related Literature}

There is some recent academic research that sheds light on the various hypothetical "expropriation" scenarios discussed here. Zingales (1994) documents evidence that shares with voting rights trade for as much as an $82 \%$ premium over the prices of shares without the right to vote. He finds that "...on average, nonvoting share have a dividend yield 1.4 times as large as the

\footnotetext{
${ }^{12}$ Given the model's assumptions this ratio is independent of time, since the expected takeover price grows in proportion to the firm's projected earnings.
} 
average dividend yield on the MSE [Milan Stock Exchange]." His explanation for this difference is that controlling shareholders have ways of extracting personal benefits from the firm, and that Italy does not fully protect minority shareholder rights. His data, however, focus on voting versus nonvoting shares. The Russian preferred shares, particularly firms like Surgutneftegaz, have a vote in certain circumstances. Thus, it is not clear that the gap can be entirely attributed to the value of the vote. In addition, the dividends to the Russian preferred shares are bounded below by dividends to common shareholders. Unless the common is closely-held by management which is potentially tempted to drain the assets of the firm through corporate perquisites and other shady mechanisms, it would seem unlikely that the Italian experience helps explain the Russian one. Furthermore, as noted earlier, management's mechanism for draining value must include relatively high cash payments to the common relative to the preferred shareholders.

Smith and Amaoko-Adu (1995) use merger data from the Toronto Stock Exchange to investigate the price gap between "super-voting" shares and common shares. They find that supervoting shares get advantageous terms in mergers $-57 \%$ on average. Thus, while the super-voting premium in share price is modest - 5 to 10 percent - the price premium commanded by super-voting shares apparently reflects advantageous merger terms times the probability that a merger will occur. While some Canadian firms have adopted "coat-tail" provisions that require acquiring firms to tender for minority shares at prices paid to the majority this protection is insufficient to guarantee that those with the lion's share of the vote do not take the lion's share of the acquisition premium.

The Russian market has both similarities and differences with the Canadian market. In one sense, the Canadian figures may underestimate the discount on Russian preferred shares since the premium of super voting shares over common shares in Canada is modest by comparison to the 
premium of Russian common prices over preferred prices. On the other hand,"coat-tail" provisions exist in Russia that limit the degree to which the preferred shareholders can have their wealth expropriated in a takeover. In particular, SG Warburg's Russian Equity Guide notes that Article 80(1) of the Law on Joint Stock Companies states that:

If an individual, legal entity and/or group of affiliated companies acquires $30 \%$ or more of a company's shares, the buyer(s) must offer to purchase all shareholder's stakes at the weighted-average market price over the previous six months. ${ }^{13}$

While this provision prevents an acquiring firm from expropriating all minority shareholder value, it does limit the amount payable to minority shareholders to the pre-acquisition price level - in other words, minority shareholders will not necessarily get any premium in a merger. Apparently, the law only requires those making a tender offer for $30 \%$ or more of a class to purchase shares in that class on a pro-rata basis. It does not impose a similar requirement across classes. Thus, it would be surprising to find that an acquiring firm did not tender first for the common, and then buy the preferred at the six-month average of the pre-acquisition price levels. Given these restrictions it would appear to be a stretch to fit the Smith and Amaoko-Adu results to the current market prices in Russia.

The hypothesis that the common shareholders earn any takeover premium while the preferred shareholders do not - would further suggest that the discount of Russian preferred shares should be higher if acquiring firms in Russia pay a high premium when they make a tender offer. This is a potentially testable hypothesis. The international mergers database SDC records 1,129 mergers or acquisitions for Russian companies. These include consummated, pending, rumored and

\footnotetext{
${ }^{13}$ Brunswick UBS Warburg, Russian Equity Guide, p.13.
} 
failed transactions involving publicly traded firms during the period. This simple count gives some measure of the merger and acquisition activity involving Russian companies since the beginning of privatization - clearly there has been an active market for corporate control in Russia, and thus the probability of an acquisition of any given company is not zero.

\section{Correlated Changes Among Firms}

The degree to which preferred shareholders (or common shareholders) are put at risk of being expropriated depends on shareholder protection, which in turn is a function of the legal and regulatory framework of corporate governance. As noted earlier the perceived risk of expropriation in Russia is so great that the president himself has made it a top priority. This section explores the extent to which there may exist a common factor related to expropriation concerns. As noted previously, a common factor - if it exists - reflects the market's interpretation of governance risks, not necessarily the true ex ante probability of such expropriation occurring. Firms in different industries may have different organizational structures, and by the nature of these structures, different corporate governance issues will have significance for the different types of firms. Still, to the degree that the common legal and regulatory environment faced by firms changes over time, there may be a common corporate governance component - of common market opinion component - in the relative valuation of preferred and common shares

The data set contains daily closing prices for common and preferred shares of the five liquid, non-financial firms. These firms are: Unified Energy System (EESR), Lukoil Holdings (LKOH), Norilsk Nickel (NKEL), Rostelecom (RTKM), and Surgutneftegas (SNGS). The data extends from October 7, 1996, the earliest date that the prices of both common and preferred shares are available 
for all five firms, to August 31, 2001. This gives yields 1,231 daily closing price observations for common and preferred shares of the five firms. The data was obtained directly from the Russian Trading System. All prices are in US dollars. Common and preferred shares of these firms account for over 53\% of the market capitalization of the RTS Index as of October 25, 2001. Although there are many more companies with preferred and common classes of shares, these are the only ones with continuous daily time series observations for both classes of shares.

All analysis in this section is performed with prices per share. For each firm $i$ for each date $t$ compute the ratio of share prices of common to preferred, $X_{i t}=P_{i t}^{c} / P_{i t}^{p}$. After that extract the principal components from the logged series, $\ln X_{i t}=\ln \left[P_{i t}^{c} / P_{i t}^{p}\right]=\ln P_{i t}^{c}-\ln P_{i t}^{p}$. The results are shown in the Table 7. A reasonably high proportion of variance can be attributed to the first component: $61 \%$-- suggestive of a common factor. Perhaps more importantly, the factor loadings for the first component are positive for all firms in the sample. This indicates the presence of a common factor to which all respond in the same way.

To test for co-movement in the relative valuation of common and preferred shares across firms a non-parametric test that focuses on directions of movements rather than magnitude is also examined. This is important because the quality of time series data may be questionable, and relatively rare events may be informative. Consider the observed ratio of common to preferred prices for firm $i$ on the date $t, X_{i t}=P_{i t}^{c} / P_{i t}^{p}$. On a given date the price of a common share, $P_{i t}^{c}$, can decrease $\left(P_{i t}^{c}<P_{i t-1}^{c}\right)$, remain unchanged, or increase, compared to the previous close. The same can be said about the price of preferred, $P_{i t}^{p}$. Suppose that on some day the price of the common decreased and the price of preferred increased. Then, on such a day, the ratio of common to preferred prices is said to have improved. This may be a day when news was released which the market interpreted as 
positive news for the preferred shareholders and negative news for the common shareholders. For example, news that expropriating preferred share value became more difficult. Define the indicator variable $Y_{i t}^{(i)}$ that takes the value of 1 on the days of improvement in the ratio, and the value of 0 , otherwise.

$$
Y_{i t}^{(i)}= \begin{cases}1, & P_{i t}^{c}<P_{i t-1}^{c} \text { and } P_{i t}^{p}>P_{i t-1}^{p} \\ 0, & \text { otherwise }\end{cases}
$$

The superscript $i$ stands for "improvement". Similarly, define the indicator variable $Y_{i t}^{(w)}$ to mark the days when the ratio of common to preferred prices had worsened, because the common price has increased while the preferred price has decreased.

$$
Y_{i t}^{(w)}=\left\{\begin{array}{ll}
1, & P_{i t}^{c}>P_{i t-1}^{c} \\
0, & \text { otherwise }
\end{array} \text { and } P_{i t}^{p}<P_{i t-1}^{p}\right.
$$

Finally, define a random variable that indicates that either common to preferred price ratio improved or it worsened on date $t, Y_{i t}^{(3)}$. This variable measures whether or not some event (either positive or negative) took place.

Tests are conducted via a pair-wise $\tilde{\chi}^{2}$ independence test for the time series of the indicator variables defined above. Table 8 contains computed values for the $\tilde{\chi}^{2}$ test statistics for each pair of companies. Consider Panel A, where the results for $Y_{i t}^{(i)}$ are reported. Out of 10 company pairs the data reject the null hypothesis of independence in ratio improvement for 7 pairs.

Panel B reports the test statistics for the tests of independence in $Y_{i t}^{(w)}$. Out of ten company pairs the null hypothesis of independence is rejected in four cases. For the $Y_{i t}^{(3)}$ variable the results are reported in Panel C. Here the null hypothesis of independence is rejected for 6 pairs out 10; for 4 of the pairs the results are significant at $1 \%$ level. Taken together the evidence seems to point to 
at least some commonality in the behavior of the relative values of common and preferred shares in the Russian market.

Since the price ratio controls for traditional market factors, the systematic changes observed in the data cannot be due to changes in the value of the overall economy. Rather the common component indicates that some central influence simultaneously changes the value of the preferred relative to the common. Off hand, changes in the perceived legal standing of each class would appear to be a good candidate for the underlying cause, thus implying that corporate control issues capture at least some of the observed price discrepancies.

\section{Conclusion}

Russia is a great market in which to study exposure to corporate governance risk. It is now the "Wild West" of corporate control. This paper examines a phenomenon that appears to violate the law of one price; the spread between preferred and common shares. The gap can only be explained by extreme scenarios relying upon immanent and major failures of investor protection. The analysis suggests that the preferred share discount is hard to explain by reasonable models of shareholder expropriation or merger, even under extremely pessimistic assumptions. The models analyzed here suggest that expropriation would have to involve the expected seizure of more than $65 \%$ of shareholder value by one class of shareholders within about four or five years to justify the current differential. Alternatively, an acquisition scenario would have to involve a huge premium, coupled with a high level of certainty that the merger would go through in order to justify the current spread in share prices. While none of these explanations can be logically ruled out, they seem improbable. By using the relative value of common and preferred shares, one can then back out and quantify the 
implied investor concerns about expropriation and compare them to feasible strategies and realistic ex ante probabilities.

The analysis is consistent with two possible explanations. First, overly-pessimistic views of the potential for management fraud may be at work. While Russian shares as a group may reflect a discount for such possibilities, the split between preferred and common shares would seem far too large to reflect anything other than extreme, and possibly unwarranted negative sentiment. Second, it may be that rational investors are simply producing price series like those found in multiple equilibria models of asset pricing such as Spiegel (1998). Differentiating between the two explanations will require additional data about corporate fundamentals.

Developing precedent and further regulatory activity may be expected to alleviate apparent shareholder concerns about the potential vulnerability of preferred claims to expropriation and takeovers, and indeed may already have caused some convergence. If nothing else, the analytic framework in this paper offers a means for investors to more formally structure their prior beliefs about adverse events. This structure, in turn, has the potential to help ascertain what a set of reasonable assumptions about such events may imply about the relative value of Russian preferred and common shares.

The price difference between Russian common and preferred shares is of much more than academic interest. For investors in the Russian market, the differential suggests the potential profitability of investing in the preferred shares, conditional upon rational evaluation of the probabilities of various corporate events that impact relative value. For Russian companies, a major concern is the cost of capital. The analysis indicates that the yields on the preferred shares are higher than is warranted by discount and growth rates implied by the common. This would suggest it is 
profitable for Russian firms to buy back their preferred shares at prevailing market prices and finance such activity with new common equity issues. Of course, if that happened, this would raise the price of the preferred shares.

The illiquidity and infrequent trading of Russian shares is a major barrier to the empirical analysis, however it should be recognized that these are endogenous factors. If, indeed, the observed ratios are due to investor fears of expropriation it might cause the public anonymous market for securities to dry up. The low point in the volume of Russian share trading occurred at the same time that the average ratio of common and preferred of the five most liquid firms reached a maximum. While macroeconomic, global factors are typically cited for the Russian 1997 crisis, it is worth considering that concerns about a corporate governance meltdown may have caused severe distortions in relative valuations in the period since the 1997 crisis. 


\section{References}

"Corporate Governance Weekly." Troika Dialog. Various Issues.

Fan, Yan, 1998, "The Foreign Share Discount in a Segmented Market," Yale University Ph.D. Thesis.

Goetzmann, William N., and Matthew Spiegel, 2000, "The Relative Valuation of Preferred and Common Shares of Russian Companies," Working Paper, International Center for Finance, Yale School of Management.

Hanouna, Paul, Atulya Sarin, and Alan C. Shapiro, 2001, "Value of Corporate Control: Some International Evidence," Working Paper No. 01-4, Marshall School of Business, USC.

Horner, Melchior R., 1988, "The Value of the Corporate Voting Right: Evidence From Switzerland," Journal of Banking and Finance 12 (1), 69-84.

Levy, Haim, 1983, "Economic Evaluation of Voting Power of Common Stock," Journal of Finance, 38 (1), 79-93.

Rockinger, Michael and Giovanna Urga, 1999, A time varying parameter model to test for predictability and integration in stock markets of transition economies, Working Paper, Social Science Research Network [www.SSRN.com]

Rydqvist, Kristian, 1996, "Takeover Bids and the Relative Prices of Shares that Differ in Their Voting Rights," Journal of Banking and Finance 20 (8, Sep), 1407-1425.

Smith, Brian F. and Ben Amoako-Adu, 1995, Relative prices of dual class shares, Journal of Financial and Quantitative Analysis 30(2), 223-239.

Spiegel, Matthew, 1998, "Stock Price Volatility in a Multiple Security Overlapping Generations Model," Review of Financial Studies 11(2), .

"The World Factbook 2001", CIA, www.odci.gov

Zingales, Luigi, 1994, The value of the voting right: a study of the Milan Stock Exchange, Review of Financial Studies 7(1), 125-148.

Zingales, Luigi, 1995, "What Determines the Value of Corporate Votes?" Quarterly Journal of Economics, 110 (4), 1047-1073. 
Table 1

Annual Dividend Payments to Common and Preferred Shares

\begin{tabular}{|c|c|c|c|c|c|c|c|c|}
\hline & & 1994 & 1995 & 1996 & 1997 & 1998 & 1999 & 2000 \\
\hline EESR & Unified Energy System & 0.001618 & 0.003236 & 0.005 & 0.005 & 0.005 & 0.006228 & 0.0131 \\
\hline EESRP & Unified Energy System & 0.001894 & 0.003788 & 0.005 & 0.005 & 0.00917 & 0.0152 & 0.0367 \\
\hline $\mathrm{LKOH}$ & LUKoil Holdings & & 0.1 & 0.5 & 0.3 & 0.22 & 0.25 & 3 \\
\hline LKOHP & LUKoil Holdings & & 0.5 & 0.5 & 1 & 0.91 & 2.67 & 17.45 \\
\hline NKEL & Norilsk Nickel & & 0.887875 & 0 & 0 & 0 & 0 & 1.77 \\
\hline NKELP & Norilsk Nickel & & 3.058491 & 0.40423 & 0.001846 & 0.01 & 0 & 1.77 \\
\hline RTKM & Rostelecom & & 0 & 0 & 0 & 0.08222 & 0 & 0.1645 \\
\hline RTKMP & Rostelecom & & 0.05 & 0.447 & 0.4756 & 0.5736 & 0 & 0.8093 \\
\hline SNGS & Surgutneftegas & & 0.0034 & 0.007 & 0.007 & 0.007 & 0.00916 & 0.02 \\
\hline SNGSP & Surgutneftegas & & 0.0052 & 0.026 & 0.026 & 0.026 & 0.00916 & 0.086 \\
\hline KUBN & Kubanelectrosvyaz & & & 0.172 & 0.53 & 0.935 & 0.6 & 1.94 \\
\hline KUBNP & Kubanelectrosvyaz & & & 2.575 & 5.299 & 7.012 & 3 & 8.32 \\
\hline LSNG & Lenenergo & & 0.003289 & 0.003 & 0.003 & 0 & 0 & \\
\hline LSNGP & Lenenergo & & 5.32 & 0.03 & 0.02 & 0 & 0 & \\
\hline SVIC & $\begin{array}{l}\text { Svyazinform of } \\
\text { Chelyabinsk }\end{array}$ & 0.034154 & 0.156077 & 0.461538 & 1.433 & 1.965 & 1.015 & 1.18 \\
\hline SVICP & $\begin{array}{l}\text { Svyazinform of } \\
\text { Chelyabinsk }\end{array}$ & & 1.373538 & 7.050769 & 12.973 & 13.341 & 4.592 & 5.936 \\
\hline TATN & Tatneft & & 0 & 0.051 & 0.06 & 0.06 & 0.04 & 0.1 \\
\hline TATNP & Tatneft & & & & & 0.1 & 0.1 & 0.15 \\
\hline
\end{tabular}

The amounts shown are per-share cash dividend amounts, in Russian rubles. Zero means that explicit decision to omit the dividend was made. Empty cell means no data is reported for the year. Common is on the first line, preferred (indicated by "P" at the end of the ticker symbol) is on the second line. The numbers shown are exact (not rounded) dividend amounts. 
Table 2

Preferred Shares in Russia - Summary Statistics

Total number of stocks in RTS Archive (stocks that once were and/or still are listed)

- Number of Common

909 stocks

- Number of Preferred

651 stocks

258 stocks

Total number of stocks in Archive with at lest 1

472 stocks

reported trade

The number of companies with both common and preferred shares in RTS Archives

Currently listed equity securities (24 Sep 2001)

Percent of RTS US\$ historical trading volume from trades in common and preferred of the dual class firms

Percent of RTS US\$ historical trading volume 251 companies from trades in preferred of the dual class firms Volume of trades in preferred as fraction of trading volume in dual class firms Percentage of market capitalization of RTS Index accounted for by preferred stocks Percentage of market capitalization of RTS Index accounted for by dual class firms in the index

389 stocks

$73 \%$

$4.5 \%$

$6.2 \%$

$5.55 \%$

$65.21 \%$ 
Table 3

Liquidity Measures: Common and Preferred Shares in Dollars and Number of Trades in 2000

\begin{tabular}{|c|c|c|c|c|}
\hline Company & Common & Preferred & Trades in & \\
\hline 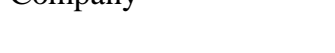 & \$ Volume & \$ Volume & Common & $\begin{array}{l}\text { 1rades in } \\
\text { Preferred }\end{array}$ \\
\hline Unified Energy System & $2,253,688,162$ & $39,158,120$ & 36,054 & 1,190 \\
\hline Lukoil & $940,120,973$ & $84,621,188$ & 8,410 & 956 \\
\hline Norilsk Nickel & $248,069,281$ & $22,186,934$ & 3,388 & 479 \\
\hline Rostelecom & $261,099,094$ & $25,580,545$ & 5,383 & 966 \\
\hline Surgutneftegaz & $501,407,145$ & $198,272,199$ & 9,084 & 3,766 \\
\hline Kubanelectrosvyaz & $6,310,558$ & $1,214,016$ & 301 & 92 \\
\hline $\begin{array}{l}\text { Svyazinform of } \\
\text { Chelyabinsk }\end{array}$ & $2,347,873$ & 929,872 & 65 & 56 \\
\hline Tatneft & $345,579,477$ & $5,841,688$ & 5,916 & 313 \\
\hline \multicolumn{5}{|c|}{ Relative to Market Value } \\
\hline Unified Energy System & 0.465 & 0.408 & & \\
\hline Lukoil & 0.119 & 0.096 & & \\
\hline Norilsk Nickel & 0.205 & 0.188 & & \\
\hline Rostelecom & 0.352 & 0.263 & & \\
\hline Surgutneftegaz & 0.056 & 0.021 & & \\
\hline Kubanelectrosvyaz & 0.060 & 0.099 & & \\
\hline $\begin{array}{l}\text { Svyazinform of } \\
\text { Chelyabinsk }\end{array}$ & 0.026 & 0.073 & & \\
\hline Tatneft & 0.345 & 0.189 & & \\
\hline \multicolumn{5}{|c|}{ Panel B: Matching U.S. Firms } \\
\hline \multicolumn{5}{|c|}{ Relative to Market Value } \\
\hline Unified Energy System & 1.344 & 2.131 & & \\
\hline Lukoil & 8.825 & 1.249 & & \\
\hline Norilsk Nickel & 1.902 & 0.827 & & \\
\hline Rostelecom & 3.001 & 1.361 & & \\
\hline Surgutneftegaz & 4.551 & 2.062 & & \\
\hline Kubanelectrosvyaz & 1.025 & 0.906 & & \\
\hline $\begin{array}{l}\text { Svyazinform of } \\
\text { Chelyabinsk }\end{array}$ & 4.270 & 1.184 & & \\
\hline Tatneft & 1.370 & 19.36 & & \\
\hline
\end{tabular}




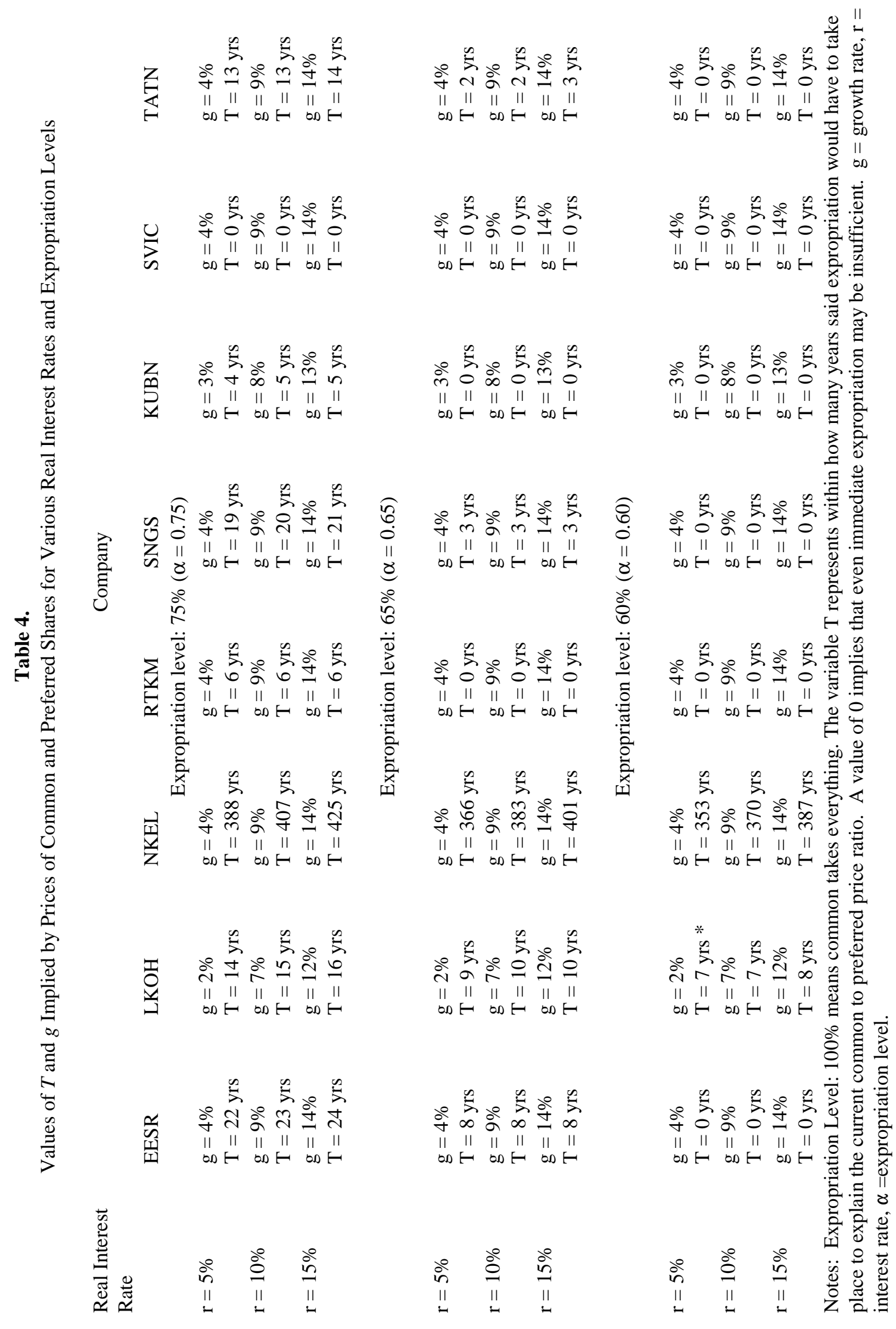


Table 5.

Values of $T$ and $g$ Implied by Prices of Common and Preferred Shares for Various Real Interest Rates and Merger Premium Levels: Payouts Estimated Using Historical Ratios

Real

Interest

Rate $\mathrm{r}$

\begin{tabular}{llllllllll} 
& & EESR & LKOH & NKEL & RTKM & SNGS & KUBN & SVIC & TATN \\
& & & \multicolumn{7}{c}{ Merger Premium: $\mathrm{m}=2$} \\
& $\mathrm{P}_{\mathrm{CT}} / \mathrm{E}_{\mathrm{T}}$ & 26.1 & 7.8 & 602.2 & 2.7 & 2.5 & 2.5 & 5.1 & 1.2 \\
$5 \%$ & $\mathrm{~g}$ & 0.024 & -0.008 & 0.043 & 0.009 & 0.025 & -0.025 & 0.019 & 0.011 \\
$10 \%$ & $\mathrm{~T}$ & 0 & 0 & 397 & 0 & 0 & 0 & 0 & 0 \\
& $\mathrm{~g}$ & 0.074 & 0.042 & 0.093 & 0.059 & 0.075 & 0.025 & 0.069 & 0.061 \\
$15 \%$ & $\mathrm{~T}$ & 0 & 0 & 416 & 0 & 0 & 0 & 0 & 0 \\
& $\mathrm{~g}$ & 0.124 & 0.092 & 0.143 & 0.109 & 0.125 & 0.075 & 0.119 & 0.111 \\
& $\mathrm{~T}$ & 0 & 0 & 435 & 0 & 0 & 0 & 0 & 0
\end{tabular}

Merger Premium: $m=10$

$\begin{array}{llllllllll} & \mathrm{P}_{\mathrm{CT}} / \mathrm{E}_{\mathrm{T}} & 95.7 & 28.5 & 2208.1 & 10.0 & 9.1 & 9.2 & 18.8 & 4.4 \\ 5 \% & \mathrm{~g} & 0.024 & -0.008 & 0.043 & 0.009 & 0.025 & -0.025 & 0.019 & 0.011 \\ & \mathrm{~T} & 22 & 7 & 632 & 0 & 4 & 0 & 0 & 23 \\ 10 \% & \mathrm{~g} & 0.074 & 0.042 & 0.093 & 0.059 & 0.075 & 0.025 & 0.069 & 0.061 \\ & \mathrm{~T} & 23 & 8 & 650 & 0 & 4 & 0 & 0 & 24 \\ 15 \% & \mathrm{~g} & 0.124 & 0.092 & 0.143 & 0.109 & 0.125 & 0.075 & 0.119 & 0.111 \\ & \mathrm{~T} & 24 & 8 & 694 & 0 & 4 & 0 & 0 & 25\end{array}$

\begin{tabular}{llllllllll} 
& & \multicolumn{9}{c}{ Merger Premium: $\mathrm{m}=20$} \\
$5 \%$ & $\mathrm{P}_{\mathrm{CT}} / \mathrm{E}_{\mathrm{T}}$ & 182.7 & 54.5 & 4215.5 & 19.2 & 17.3 & 17.6 & 35.9 & 8.4 \\
& $\mathrm{~g}$ & 0.024 & -0.008 & 0.043 & 0.009 & 0.025 & -0.025 & 0.019 & 0.011 \\
$10 \%$ & $\mathrm{~T}$ & 50 & 19 & 733 & 9 & 32 & 8 & 0 & 41 \\
& $\mathrm{~g}$ & 0.074 & 0.042 & 0.093 & 0.059 & 0.075 & 0.025 & 0.069 & 0.061 \\
$15 \%$ & $\mathrm{~T}$ & 52 & 20 & 768 & 9 & 34 & 8 & 0 & 43 \\
& $\mathrm{~g}$ & 0.124 & 0.092 & 0.143 & 0.109 & 0.125 & 0.075 & 0.119 & 0.111 \\
& $\mathrm{~T}$ & 55 & 21 & 803 & 10 & 35 & 9 & 0 & 45
\end{tabular}

Notes: The model takes the merger premium and the interest rate $\mathrm{r}$ as given and then solves for $\mathrm{g}$ and $\mathrm{T}$. Merger Premium: 1 equals a 100\% premium, 10 a 1000\% premium, etcetera. The value of T states that the current common to preferred price ratio can only be explained if a takeover occurs within $\mathrm{T}$ years, the firm continues to grow at a rate $\mathrm{g}$ between now and then, and the discount rate equals $\mathrm{r}$. A value of $\mathrm{T}=0$ implies an immediate takeover at the multiple of $\mathrm{m}$ will not equilibrate the value of the preferred and common shares. $\mathrm{P}_{\mathrm{CT}} / \mathrm{E}_{\mathrm{T}}$ equals the model's implied price-earnings ratio for the common shares at the takeover date $\mathrm{T}$. This value depends only upon the implied growth and interest rates, and not on $\mathrm{T}$, since the takeover price is assumed to grow proportionately with earnings. 
Table 6.

Values of $T$ and $g$ Implied by Prices of Common and Preferred Shares for Various Real Interest Rates and Merger Premium Levels: Payouts Assume the Common Receives an Amount Equal to the Preferred

Real

Interest

Rate $\mathrm{r}$

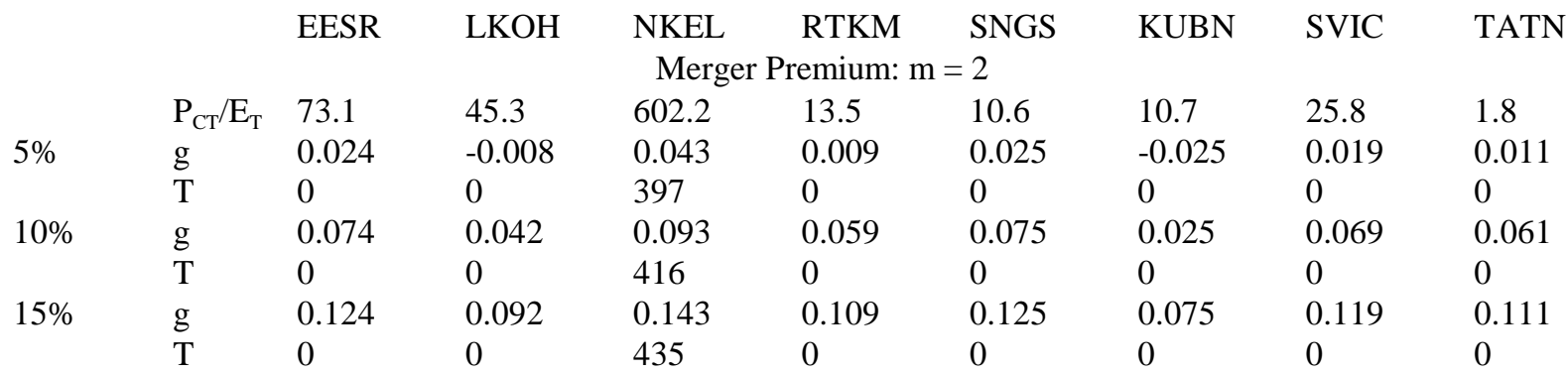

Merger Premium: $m=10$
166.0

$\begin{array}{llllll} & \mathrm{P}_{\mathrm{CT}} / \mathrm{E}_{\mathrm{T}} & 268.1 & 166.0 & 2208.1 & 49.4 \\ 5 \% & \mathrm{~g} & 0.024 & -0.008 & 0.043 & 0.009 \\ & \mathrm{~T} & 22 & 7 & 632 & 0 \\ 10 \% & \mathrm{~g} & 0.074 & 0.042 & 0.093 & 0.059 \\ & \mathrm{~T} & 23 & 8 & 650 & 0 \\ 15 \% & \mathrm{~g} & 0.124 & 0.092 & 0.143 & 0.109 \\ & \mathrm{~T} & 24 & 8 & 694 & 0\end{array}$

\begin{tabular}{llllllllll} 
& & \multicolumn{8}{c}{ Merger Premium: $\mathrm{m}=20$} \\
$5 \%$ & $\mathrm{P}_{\mathrm{CT}} / \mathrm{E}_{\mathrm{T}}$ & 511.8 & 316.8 & 4215.5 & 94.3 & 74.4 & 75.5 & 180.4 & 12.6 \\
& $\mathrm{~g}$ & 0.024 & -0.008 & 0.043 & 0.009 & 0.025 & -0.025 & 0.019 & 0.011 \\
& $\mathrm{~T}$ & 50 & 19 & 733 & 9 & 32 & 0 & 0 & 41 \\
$10 \%$ & $\mathrm{~g}$ & 0.074 & 0.042 & 0.093 & 0.059 & 0.075 & 0.025 & 0.069 & 0.061 \\
& $\mathrm{~T}$ & 52 & 20 & 768 & 9 & 34 & 0 & 0 & 43 \\
$15 \%$ & $\mathrm{~g}$ & 0.124 & 0.092 & 0.143 & 0.109 & 0.125 & 0.075 & 0.119 & 0.111 \\
& $\mathrm{~T}$ & 55 & 21 & 803 & 10 & 35 & 0 & 0 & 45
\end{tabular}

Notes: Historically the common has received a lower dividend per share than the preferred. The calculations in this table assume that going forward the common will receive an amount equal to the preferred, which is the maximum allowed by law. The model takes the merger premium and the interest rate $\mathrm{r}$ as given and then solves for $\mathrm{g}$ and $\mathrm{T}$. Merger Premium: 1 equals a 100\% premium, 10 a 1000\% premium, etcetera. The value of $\mathrm{T}$ states that the current common to preferred price ratio can only be explained if a takeover occurs within $\mathrm{T}$ years, the firm continues to grow at a rate $\mathrm{g}$ between now and then, and the discount rate equals $\mathrm{r}$. A value of $\mathrm{T}=0$ implies an immediate takeover at the multiple of $m$ will not equilibrate the value of the preferred and common shares. $\mathrm{P}_{\mathrm{CT}} / \mathrm{E}_{\mathrm{T}}$ equals the model's implied price-earnings ratio for the common shares at the takeover date $\mathrm{T}$. This value depends only upon the implied growth and interest rates, and not on $\mathrm{T}$, since the takeover price is assumed to grow proportionately with earnings. 
Table 7.

Principal Components Analysis

Importance of Components

Standard

Deviation

Component 1

Component 2 Component 3

Component 4 Component 5

Proportion of

Variance

$1.748 \quad 1.062$

0.746

0.419

0.292

Cumulative

Proportion

$0.611 \quad 0.225$

0.111

0.036

0.017

$0.611 \quad 0.836$

0.947

0.983

1.000

Factor Loadings

EESR

Component 1 Component 2 Component 3

Component 4

Component 5

0.504

$-0.222$

$-0.350$

$-0.758$

$-0.009$

$\mathrm{LKOH}$

0.430

0.371

0.686

$-0.135$

$-0.435$

$0.161 \quad 0.820$

$-0.536$

0.115

$-0.023$

0.486

$-0.375$

$-0.285$

0.570

$-0.466$

0.548

0.005

0.195

0.263

0.770 
Table 8.

Chi-Square Tests of Independence

Panel A $\quad$ Panel B

Improvement in the Common to Preferred Price Ratio.

Chi-Square Test Statistics.

\begin{tabular}{lccccc|l} 
& EESR & LKOH & NKEL & RTKM & SNGS & \\
EESR & & $\mathbf{5 . 8 4 1} * *$ & 0.141 & $\mathbf{4 . 3 1 6}^{* *}$ & $\mathbf{3 . 2 4 4} *$ & EESR \\
LKOH & $\mathbf{5 . 8 4 1} * *$ & & $\mathbf{4 . 8 4 2} * *$ & 0.145 & $\mathbf{8 . 6 9 3} * * *$ & LKOH \\
NKEL & 0.141 & $\mathbf{4 . 8 4 2} * *$ & & $\mathbf{3 . 1 7 7} *$ & 0.596 & NKEL \\
RTKM & $\mathbf{4 . 3 1 6}^{* *}$ & 0.145 & $\mathbf{3 . 1 7 7} *$ & & $\mathbf{4 . 8 3 4}^{* *}$ & RTKM \\
SNGS & $\mathbf{3 . 2 4 4}^{*}$ & $\mathbf{8 . 6 9 3} * * *$ & 0.596 & $\mathbf{4 . 8 3 4 * *}$ & & SNGS
\end{tabular}

Worsening of the Common to Preferred Price Ratio. Chi-Square Test Statistics.

$\begin{array}{ccccc}\text { EESR } & \text { LKOH } & \text { NKEL } & \text { RTKM } & \text { SNGS } \\ & \mathbf{1 3 . 2 9 9} * * * & 2.324 & \mathbf{1 4 . 3 6 8} * * * & 1.874 \\ \mathbf{1 3 . 2 9 9} * * * * & & \mathbf{3 . 2 8 4} * & 0.002 & 2.499 \\ 2.324 & \mathbf{3 . 2 8 4} * & & \mathbf{5 . 7 8 9} * * & 0.747 \\ \mathbf{1 4 . 3 6 8} * * * & 0.002 & \mathbf{5 . 7 8 9} * * & & 0.002 \\ 1.874 & 2.499 & 0.747 & 0.002 & \end{array}$

Critical values for $10 \%, 5 \%$, and $1 \%$ significance levels are 2.706, 3.841, and 6.635, respectively. Based on Chi-Square distribution with 1 degree of freedom.

\begin{tabular}{|c|c|c|c|c|c|c|c|c|c|c|c|}
\hline \multicolumn{6}{|c|}{$\begin{array}{c}\text { Panel C } \\
\text { Days classified into three categories. Chi-Square Test Statistics. }\end{array}$} & \multicolumn{6}{|c|}{$\begin{array}{l}\text { Panel D } \\
\text { Days classified into three categories. Pearson Correlations. }\end{array}$} \\
\hline EESR & EESR & $\begin{array}{c}\text { LKOH } \\
19.085 * * *\end{array}$ & $\begin{array}{l}\text { NKEL } \\
6.673\end{array}$ & $\begin{array}{c}\text { RTKM } \\
23.94 * * *\end{array}$ & $\begin{array}{c}\text { SNGS } \\
6.474\end{array}$ & EESR & EESR & LKOH & NKEL & RTKM & \multirow[t]{6}{*}{ SNGS } \\
\hline LKOH & $19.085 * * *$ & & $8.945 *$ & 0.196 & $20.784 * * *$ & LKOH & $\begin{array}{c}\mathbf{0 . 0 7 1} \\
(0.013)\end{array}$ & & & & \\
\hline NKEL & 6.673 & $8.945 *$ & & $18.055 * * *$ & 5.139 & NKEL & $\begin{array}{c}0.037 \\
(0.200)\end{array}$ & $\begin{array}{c}\mathbf{0 . 0 7 3} \\
(0.011)\end{array}$ & & & \\
\hline RTKM & $23.94 * * *$ & 0.196 & $18.055 * * *$ & & $8.986 *$ & RTKM & $\begin{array}{c}\mathbf{0 . 1 0 3} \\
(0.000)\end{array}$ & $\begin{array}{c}0.005 \\
(0.862)\end{array}$ & $\begin{array}{c}\mathbf{0 . 0 9 6} \\
(0.001)\end{array}$ & & \\
\hline SNGS & 6.474 & $20.784 * * *$ & 5.139 & 8.986* & & SNGS & $\begin{array}{r}\mathbf{0 . 0 6 2} \\
(0.030) \\
\end{array}$ & $\begin{array}{r}\mathbf{0 . 1 2 5} \\
(0.000)\end{array}$ & $\begin{array}{c}0.009 \\
(0.766)\end{array}$ & $\begin{array}{c}\mathbf{0 . 0 8 0} \\
(0.005) \\
\end{array}$ & \\
\hline \multicolumn{6}{|c|}{$\begin{array}{l}\text { Critical values for } 10 \%, 5 \% \text {, and } 1 \% \text { significance levels are } 7.779 \text {, } \\
9.488 \text {, and } 13.277 \text {, respectively. Based on Chi-Square distribution } \\
\text { with } 4 \text { d.f. }\end{array}$} & \multicolumn{5}{|c|}{ Cell contents: correlation ( $p$-value). } & \\
\hline
\end{tabular}

\footnotetext{
Data: Closing stock prices from RTS.
} 
Figure 1

RTS Index and RTS Daily Trading Volume

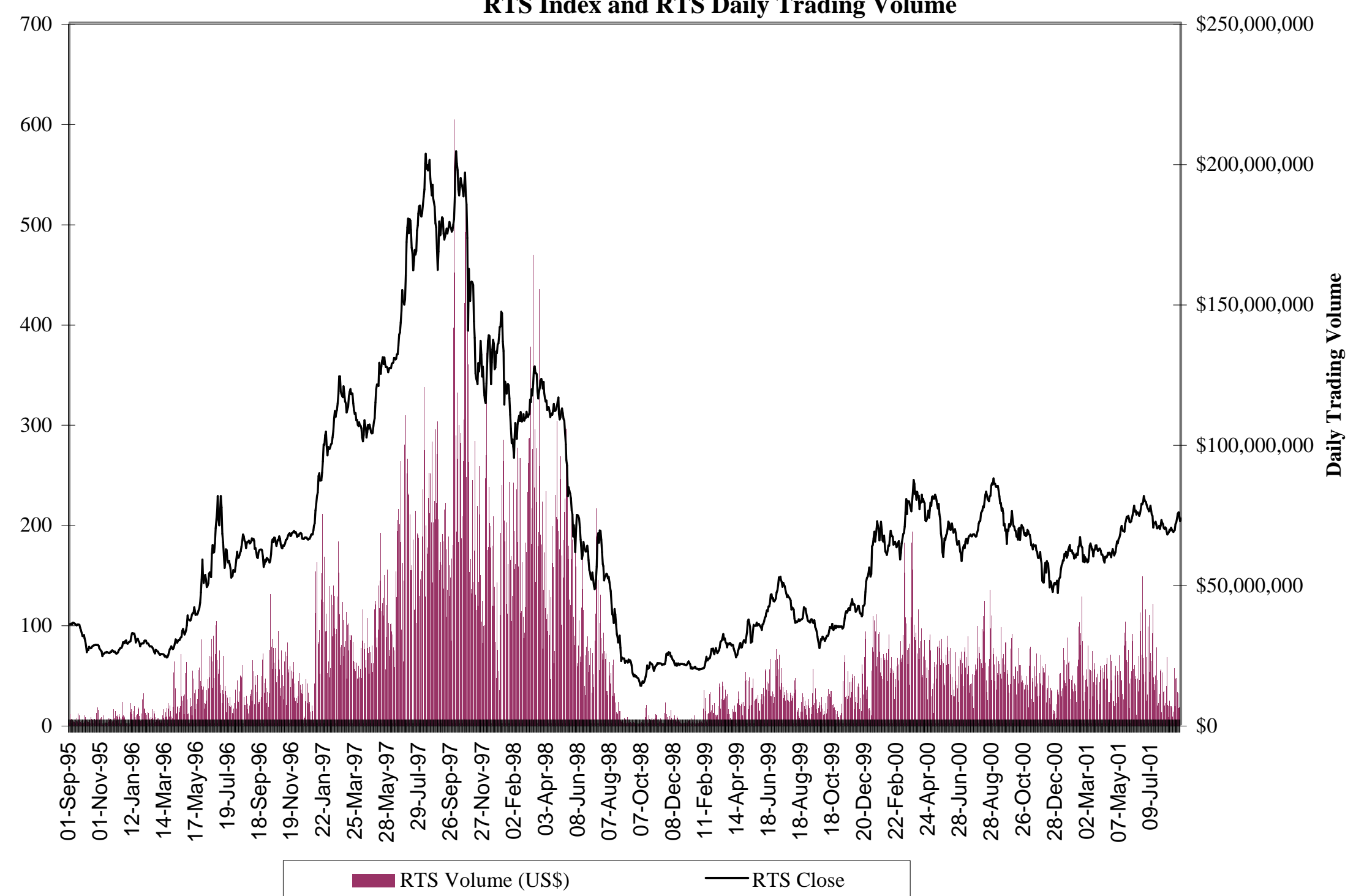




\section{Figure 2}

Equally Weighted Index: Ratio of Common to Preferred Prices (5 Liquid Firms)

and RTS Index

7-Oct-1996 - 31-Aug-2001

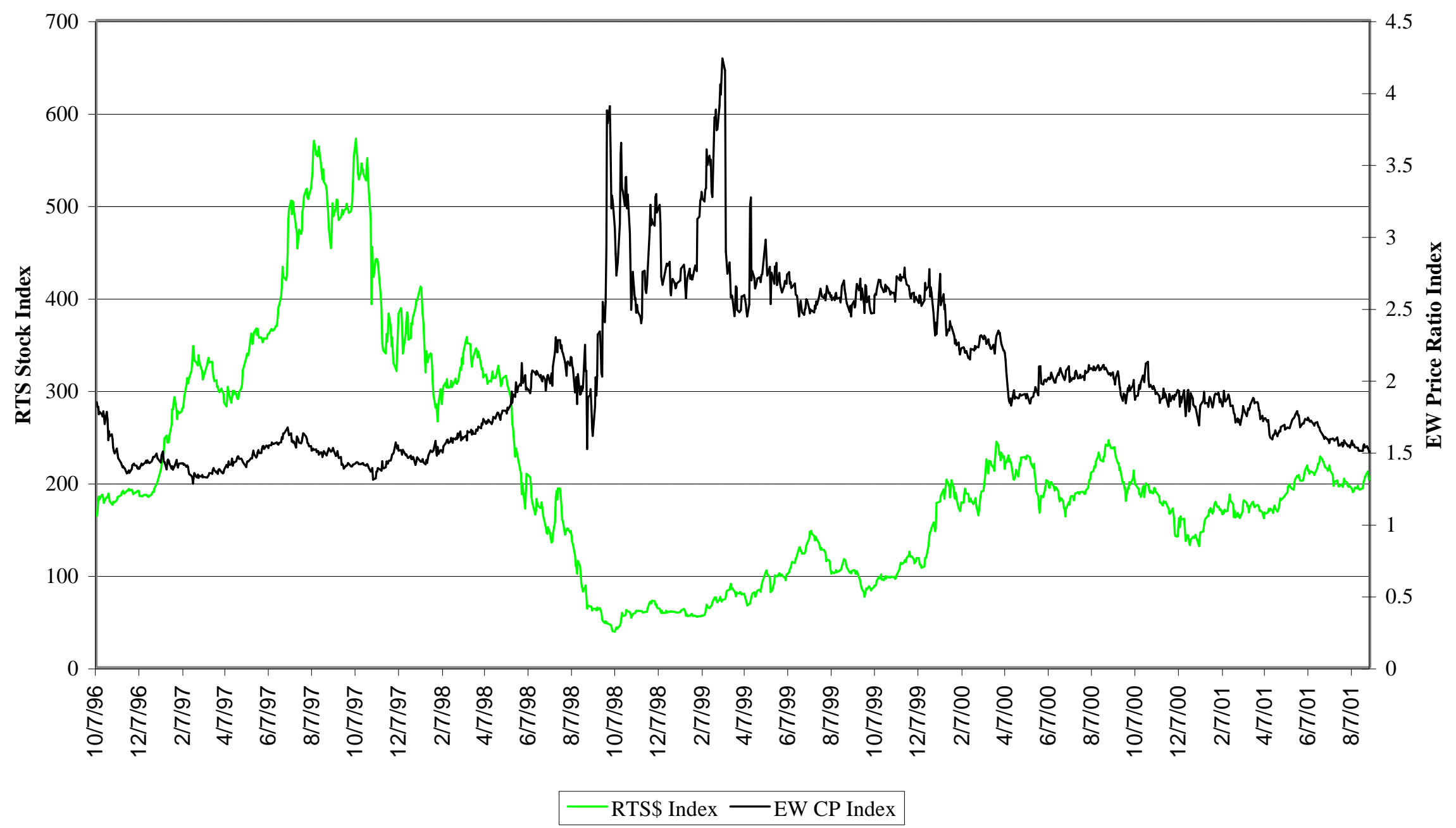


Figure 3

Common and Preferred Shares. Closing Daily Prices in US\$

Five Firms, The period: 7-Oct-1996 - 31-Aug-2001
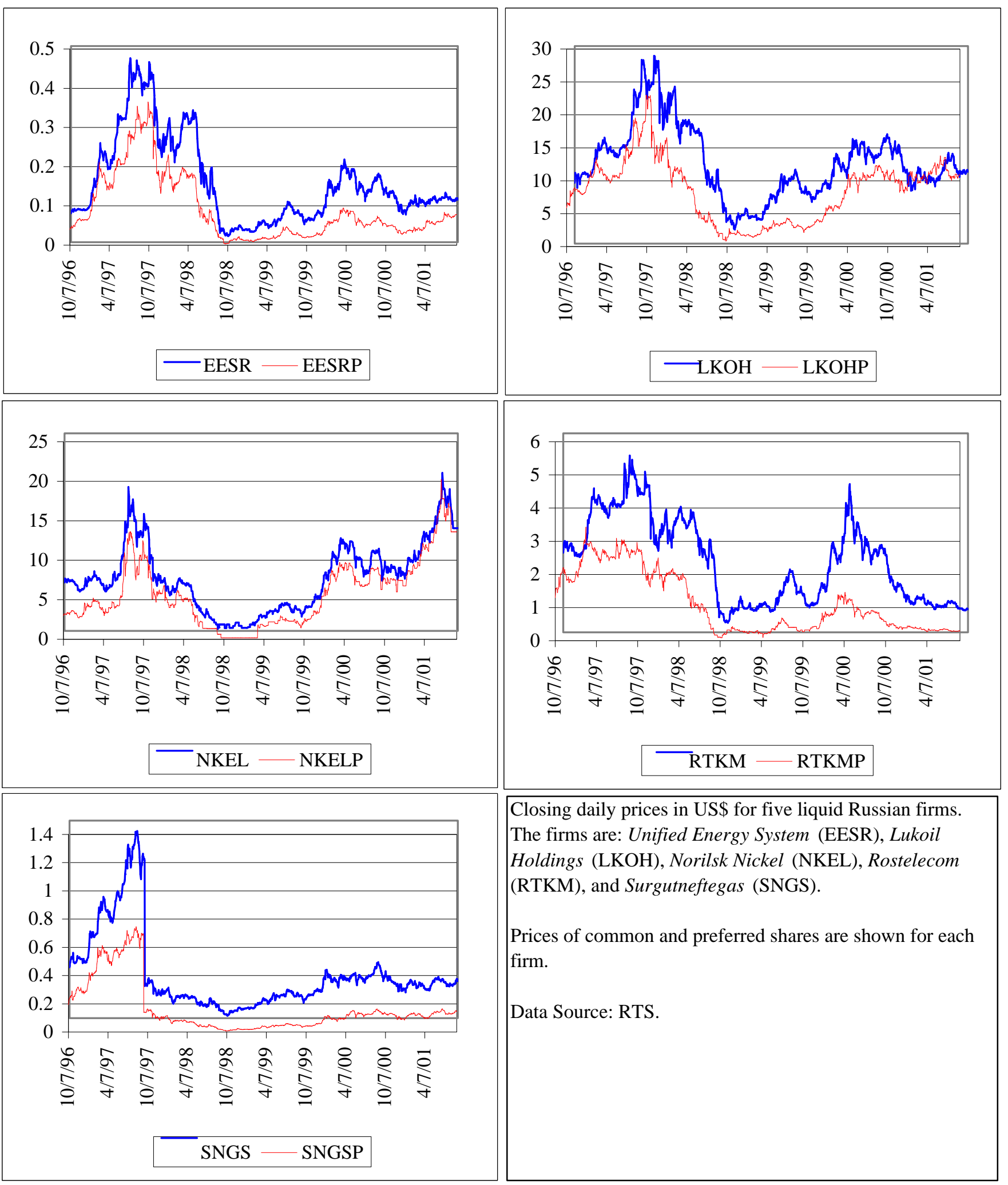

Closing daily prices in US\$ for five liquid Russian firms. The firms are: Unified Energy System (EESR), Lukoil Holdings (LKOH), Norilsk Nickel (NKEL), Rostelecom (RTKM), and Surgutneftegas (SNGS).

Prices of common and preferred shares are shown for each firm.

Data Source: RTS. 